\title{
ASSESSMENT
}

\section{Transforming the STEM Learning Experience: Minority Students' Agency in Shaping Their Own Interdisciplinary Undergraduate Research}

Shearon Roberts, Ross Louis,

Xavier University of Louisiana

\begin{abstract}
This study explores how African American STEM students pursued research experiences outside of STEM disciplines, drawing on nine years of data from the undergraduate research journal XULAneXUS at the STEMfocused, historically black institution Xavier University of Louisiana. Findings indicate that a successful STEM education for black students benefits from non-STEM research mentorship that supports and reinforces minority students' commitment to STEM careers. Data show that STEM students engaged in non-STEM research to help them study and explain phenomena, revealing significance in the agency of STEM students to broaden the scope of their STEM education at a STEM-focused institution.
\end{abstract}

Keywords: minority STEM students, HBCUs, interdisciplinary research, liberal arts education, undergraduate research

doi: $10.1833 /$ spur/2/2/6

Historically black colleges and universities (HBCUs) remain the leaders in educating African American students for STEM (science, technology, engineering, and mathematics) degrees (Museus et al. 2011). The study described here looked closely at undergraduate research at Xavier University of Louisiana, one of the leading HBCUs producing African American STEM graduates. The study examined nine years of data from the university's undergraduate research journal. The research projects pursued by undergraduate students highlight the ways in which African American students sought to enhance their own educational experience through scholarship.

24 Scholarship and Practice of Undergraduate Research
In 2011, African Americans made up only 6 percent of STEM professionals nationally (US Department of Education 2016). In 2016, roughly 65 percent of Xavier University's undergraduates were enrolled in STEM programs (Haynes 2015). Thus, Xavier University presents a unique academic space for inquiry. The support provided by Xavier University to sustain its STEM education offers lessons for how higher education institutions can best prepare black students who defy national trends in STEM careers (Owens et al. 2012). This study examined the engagement of black students at Xavier in undergraduate research activity-primarily of a non-STEM naturethrough analysis of nine years of data collected by the university's undergraduate research journal XULAneXUS. As the journal's content often features student-originated research, it tends to differ from other types of undergraduate research in which STEM students work in labs as research assistants and may copublish on research projects of their faculty research mentors. Through the undergraduate research journal, students discuss their primarily conceived and executed research activity based on their own intellectual curiosity rather than the research agenda of a faculty member.

Therefore, this study defined this type of interdisciplinary undergraduate research activity as a form of agency. More important, such research activity is a space for students to mold their educational experience as STEM majors. The STEM student's curriculum is primarily discipline focused, with both coursework and research exposure directly related to study within their major. Given the low levels of matriculation into STEM fields and careers by African American students, especially at majority institutions (Strayhorn et al. 2014), this study asked what can 
be learned when STEM students exhibit agency in undergraduate research that ultimately supports their successful completion of a STEM degree.

\section{The Institution}

Xavier University of Louisiana is the only black Catholic university in the United States, is one of 104 historically black colleges and universities in the United States, and ranks first among all US universities for black students who graduate with bachelor's degrees in biology and physics. Its stated mission is to train graduates whose work leads to a more "just and humane society" (Xavier University of Louisiana 2016). To shape the Xavier graduate, Xavier's core curriculum exposes STEM students to theology, philosophy, social sciences, fine arts, humanities, and interdisciplinary programs (Xavier University of Louisiana College of Arts and Sciences 2016). As a result, Xavier students may arrive at the university with the expectation of becoming a doctor, but the liberal arts curriculum influences the type of medical research engaged in by students or the future engineering solutions invented by students.

Of all US universities, Xavier has the highest number of black students who apply to and graduate from medical school. Xavier is in the top four of all US universities for producing black pharmacists. The university also ranks in the top three of all US universities for producing black graduates who complete doctorates in science and engineering (Hannah-Jones 2015).

\section{The Undergraduate Research Journal}

XULAneXUS was first published in 2002 with grant support from the Andrew W. Mellon Foundation. The review board is composed of a faculty editor, a student editorial assistant, a student editorial board, and faculty reviewers. Each student who submits to the journal must have a faculty mentor. Students submit research in four categories: research manuscripts, scholarly notes, creative scholarship, and service-learning analysis. There must be consensus between student and faculty reviewers on submissions. Accepted submissions are published twice during the academic year.

This article examines nine years of these submissionsfrom 2007, when systematic tracking of submissions began, to 2016. The authors analyze relationships between a student's field of study and the disciplinary nature of a student's research project, as well as the relationship between students and faculty mentors. Of particular interest is how students at an institution with a STEM focus exhibit agency by pursuing research activity outside of their disciplines and sometimes unrelated to their STEM majors.

\section{The Liberal Arts Education}

Xavier emphasizes that its "core curriculum is the basis of our liberal arts education" (Xavier University of Louisiana
2016). The purpose of a liberal arts core is to have students "think outside their narrow specializations" and to "think outside of our habitual frameworks about who we are" (Fitzsimmons 2016, 31). Being exposed to other disciplines allows students to see connectivity in the human experience. The liberal arts education offers students a journey of self-examination that allows for inquiry, reflection, and consciousness of "responsible citizenship" (Fitzsimmons 2016, 31). It is a confluence of concepts of liberty, ethics, and duty in society (Pangle 2013, 207). Finally, the liberal arts education "cultivates lifelong learning" (Fitzsimmons 2016, 32). The HBCU experience is one that supports Fitzsimmons's assertion that a "broad liberal arts curriculum ... impels innovative integrative learning that cultivates new directions in thought and impassioned action toward social justice" $(2016,31)$.

\section{The HBCU Environment and STEM Learning}

Black students were just as likely as white students to choose a STEM major (Moakler and Kim 2014, 140); where black students fell behind was in "STEM degree persistence, STEM degree completion and STEM career choice upon graduation" (140). At predominantly white institutions, minority students stated that they were unsupported in their pursuit of STEM careers (McClain 2014, 390). In one study at a majority institution, Strayhorn and colleagues noted that African American STEM students described their learning experience as the following: "“chilly' campus environments, unsupportive faculty members, strong familial obligations, and very few same-race peers upon whom they can rely for support and friendship" (2014, 2-3). On the other hand, in the HBCU environment, black STEM students said that they were driven to pursue STEM degree completion because they wanted to "prove them wrong" (Smith et al. 2014, 11). Them meant society and the stigma surrounding black intellectual ability. At the HBCU, success in the sciences was a way to defy the status quo and prove society wrong (Smith et al. 2014, 11). In researching the HBCU environment, Owens and colleagues (2012) found that the overrepresentation of black students at an HBCU was a factor that led to a more supportive learning environment among peers. Additional factors that distinguished the HBCU environment from majority institutions included the small-class sizes, faculty accessibility, encouragement and support, academic support, tutoring, peer mentorship, and community-based service learning (Fakayode et al. 2014; Farinde, Tempest, and Merriweather 2014; Museus et al. 2011, 62; Palmer, Maramba, and Dancy 2011; Perna et al. 2009). In a 2010 qualitative study, minority students at HBCUs said that faculty engagement outside of the classroom, even in their homes, made black students at HBCUs feel part of a faculty member's extended family (Fries-Britt, Younger, and Hall 2010). The HBCU environment also sought to connect learning objectives to a higher purpose. Fife, Bond, and Byars-Winston (2011, 
146) identified "self-efficacy, ethnic identity and spirituality" as outcomes tied to academic success at HBCUs.

The liberal arts education and the mission of HBCUs impact STEM degree persistence and completion and future career choice for African American students. The type of research pursued by STEM students, particularly outside of their majors, was assessed to determine the influence of the liberal arts education at Xavier. The following research questions were posed:

$R Q 1$. What research interests do STEM students at a STEM-focused HBCU have in non-STEM disciplines?

$R Q 2$. To what extent does a faculty mentor's discipline impact STEM student inquiry in research projects in non-STEM topics?

$R Q 3$. How does a liberal arts core encourage interdisciplinary research activity at a STEM-focused HBCU?

\section{Methods}

\section{Sample}

The study examined nine years of data, maintained by the XULAneXUS journal editor from 2007 to 2015. All student submissions to the undergraduate journal included the student's major, discipline, and the title of the submission, among other descriptive variables. The dataset also included information about the faculty mentor for each submission. The sample yield was 142 submissions over the nine years. The journal's acceptance rate was 58 percent.

\section{Procedure}

First, the researchers coded students, mentors, and submissions to the journals by program and by discipline. At Xavier, programs are grouped into divisions by parent disciplines: fine arts and humanities, social and behavioral sciences, business, and STEM. The psychology program at Xavier is housed in social and behavioral sciences, but faculty and students in psychology have strong ties to STEM programs through coursework and grants. Psychology also is a STEM-designated program at Xavier University for National Institutes of Health initiatives and some National Science Foundation projects. Psychology faculty teach and conduct research on neuroscience and mental health. Some psychology students also have joint majors or minors in biology, chemistry, or physics. For this reason, the researchers coded psychology separately from the social and behavioral sciences discipline, as it also is designated as a STEM field.

\section{Coding Variables}

The title of each submission by a student was used to evaluate three variables, coded 0 for No and 1 for Yes in SPSS. The three variables for submission titles are listed below.

Variable 1. Is the submission a topic primarily in the student's discipline? $(0=$ No; 1 = Yes $)$. To code this variable, it was determined whether the student's research project

26 Scholarship and Practice of Undergraduate Research was based on research in his or her field. For instance, if a student was a pharmacy major and the research project was about the effect of a specific drug, the coder would enter 1 for Yes. If the student was a biology major and the research project was about the genetic mutation of cancer cells, the coder would enter a 1, or Yes. If a student was a chemistry major and the research submission examined the literary works of Chinua Achebe, the coder would select 0 , or No.

Variable 2. Is the submission indirectly connected to the student's discipline? $(0=$ No; $1=$ Yes) When coding this variable, the coder determined whether the student's topic was related to the student's discipline either as a subfield or in an interdisciplinary context. For instance, if a psychology student submitted a historical scholarly note on slavery to answer questions about the creation of African American male stereotypes, the coder entered a 1 (Yes) for this variable. This demonstrated that the research project was indirectly connected to the student's major.

Variable 3. Is the submission theme directly related to the mentor's discipline? $(0=$ No; $1=$ Yes $)$ This variable was coded with the same guidelines as the first variable.

\section{Results}

\section{Description}

The highest number of submissions to the journal came from psychology majors, with 50 submissions (35.2 percent) over the nine years. Biology and premedicine were second with 25 submissions (17.6 percent). For discipline groups, STEM majors had the largest number of submissions (31.7 percent), with the social sciences second (18.3 percent). If psychology submissions (33.1 percent) were added to either the STEM or social sciences division, that discipline would have the highest number of submissions.

The largest number of mentors came from the psychology department (33.1 percent). The second largest group of mentors came from the English department at 19 percent, followed by the history and sociology departments at 7.7 percent each and the political science department at 6.3 percent. When departments were grouped by discipline, with psychology isolated from the disciplines, the largest number of faculty mentors came from fine arts and humanities at 32.4 percent, followed by the social sciences at 21.8 percent and STEM fields at 10.6 percent. Psychology mentors would add 33.1 percent to a discipline grouping.

\section{Research Fields}

$R Q 1$. What research interests do STEM students at a STEM-focused HBCU have in non-STEM disciplines?

Table 1 shows whether students' research projects were related to their actual majors. Chemistry, biology or premed, and history were the top three majors, in that order, 
when students submitted research for publication in subject matters unrelated to their majors. Sociology, psychology, and philosophy were the top three majors for which at least two research submissions were within students' respective disciplines. A Chi-Square test of independence examined whether there was a relationship between a student's major and the submission of research on a topic outside of the major. The relationship between these categories was significant: $X^{2}(16,142)=35.289, p=0.004$. The Chi-Square test showed a significant difference in whether students submitted research for publication in the same field as their majors at the $p<0.05$ level.

Figure 1 shows that STEM majors had the highest number of submissions for research topics unrelated to their discipline, when psychology was isolated. The social sciences, inclusive of psychology, had the largest number of students submitting research for publication related to their own discipline.

$R Q 2$. To what extent does a faculty mentor's discipline impact student inquiry in research projects in non-STEM topics?

The majority of faculty mentors came from the psychology department (33.1 percent), followed by the English department (19 percent), and history and sociology at 7.7 percent each. When faculty were grouped by discipline and psychology (33.1 percent) was isolated, the largest number of faculty mentors came from fine arts and humanities at 33.1 percent and carried the same number as psychology, $N=47$. The second largest number of mentors came from the social sciences at 21.8 percent, followed by STEM fields at 10.6 percent. Figure 2 shows the ratio of students by their disciplines, and Figure 3 shows the ratio of mentors by their disciplines. STEM majors were the second largest group except for psychology majors, but fine arts and humanities had the largest mentor group after psychology. Figure 4 reflects the response for variable 3: Is the submission theme directly related to the mentor's discipline? The results were 94.4 percent Yes and 5.6 percent No, as shown in Figure 4.

$R Q 3$. How does a liberal arts core encourage interdisciplinary research activity at a STEM-focused HBCU?

Variable 2 asked if the submission theme was indirectly connected to the student's discipline. The results for this variable were 66.9 percent Yes $(N=95)$ and 33.1 percent No $(N=47)$. Therefore, a majority of students researched topics that had some connection to their majors, as shown in Figure 5.

\section{Discussion}

RQ 1 asked: What research interests do STEM students at a STEM-focused HBCU have in non-STEM disciplines?
Table 1 and Figure 1 show that STEM students were most likely to submit research that was not related to their discipline, whereas sociology, psychology, and philosophy majors submitted research to the journal on topics in their discipline. This finding was significant. It shows that STEM students demonstrated agency when choosing research topics unrelated to their STEM disciplines. The results for RQ2 also provide an explanation for the findings in RQ1.

RQ2 asked: To what extent does a faculty mentor's discipline impact student inquiry in research projects in non-STEM topics? The highest number of faculty mentors were in fine arts and humanities departments, after isolating psychology, followed by faculty in the social sciences. The lowest number of faculty mentors came from the STEM departments and business. There was an even match between psychology mentors and psychology student submissions within this discipline. Student submissions overwhelmingly were based on topics that were in the faculty mentor's discipline. Therefore non-STEM faculty supported the agency of STEM students in interdisciplinary and non-STEM research activities.

The mentorship of STEM students by non-STEM faculty reflects both student agency and the influence of the liberal arts education core. STEM students were able to pursue STEM research projects on their own but chose to explore research topics with faculty mentors outside of their own discipline. STEM students traditionally encounter nonSTEM faculty through their core courses in philosophy, fine arts, history, political science, English, and so forth, as part of the liberal arts core curriculum. Through these required courses that support their STEM education, they can identify new subject matter and non-STEM faculty to guide them in non-STEM or interdisciplinary research projects. Both their intellectual curiosity and the liberal arts education explain this finding.

It would be expected that, at an institution with 65 percent of its majors enrolled in STEM degrees, there would be a higher ratio of STEM students to STEM faculty when compared to other programs. Therefore, non-STEM faculty are more accessible and available to mentor STEM students in interdisciplinary research. STEM faculty have a higher ratio of students in their courses and their labs and as advisees, and students primarily work on STEM research projects in the labs of STEM faculty members.

RQ3 asked: How does a liberal arts core encourage interdisciplinary research activity at a STEM-focused HBCU? Results indicate that the liberal arts core fosters more interdisciplinary research activity by STEM students than nonSTEM students. Here, non-STEM faculty are serving as mentors at a STEM-based HBCU because STEM students are seeking them out and because the liberal arts education 
TABLE 1. Is the Submission a Topic Primarily in the Student's Major?

\begin{tabular}{|c|c|c|c|}
\hline Major & No $\%(N)$ & Yes $\%(N)$ & Total $(N)$ \\
\hline Psychology & $22.9 \%(16)$ & $68 \%(34)$ & 50 \\
\hline English & $42.9 \%(3)$ & $57.1 \%(4)$ & 7 \\
\hline Political science & $62.5 \%(5)$ & $37.5 \%(3)$ & 8 \\
\hline Business & $0 \%(0)$ & $100 \%$ & 1 \\
\hline Communication studies & $50 \%(2)$ & $50 \%(2)$ & 4 \\
\hline Physics & $33.3 \%(1)$ & $66.7 \%(2)$ & 3 \\
\hline Mathematics & $0 \%(0)$ & $100 \%(1)$ & 1 \\
\hline Chemistry & $87.5 \%(7)$ & $12.5 \%(1)$ & 8 \\
\hline History & $63.6 \%(7)$ & $36.4 \%(4)$ & 11 \\
\hline Biology, premed & $84 \%(21)$ & $16 \%(4)$ & 25 \\
\hline Philosophy & $33.3 \%(1)$ & $66.7 \%(2)$ & 3 \\
\hline Art & $50 \%(1)$ & $50 \%(1)$ & 2 \\
\hline Speech pathology & $0 \%(0)$ & $100 \%(2)$ & 2 \\
\hline Pharmacy & $57.1 \%(4)$ & $42.9 \%(3)$ & 7 \\
\hline Sociology & $12.5 \%(1)$ & $87.5 \%(7)$ & 8 \\
\hline Public health & $100 \%(1)$ & $0 \%(0)$ & 1 \\
\hline Computer science & $0 \%(0)$ & $100 \%(1)$ & 1 \\
\hline Total & $\mathrm{No}=49.3 \%(70)$ & Yes $=50.7 \%(72)$ & $N=142$ \\
\hline
\end{tabular}

Note: $X^{2}(16,142)=35.289, p=0.004$

is bringing STEM students into direct contact with nonSTEM faculty through core courses. The instruction and mentorship received by STEM students when they take liberal arts courses outside of their majors allows them to explore questions unrelated to the sciences or those partly related to their STEM learning, as they consider how their major, passions, and career goals connect to the arts, history, politics, philosophy, and theology.

\section{Limitations and Future Research}

This study finds that African American students at a STEM-focused HBCU are interested in research outside of the sciences and research of an interdisciplinary nature that informs their science education. STEM students see non-STEM faculty as mentors in this research exercise. The primary way STEM students meet non-STEM faculty is through a liberal arts core curriculum, requiring students to take courses outside of their majors.

28 Scholarship and Practice of Undergraduate Research
The findings are limited to data gathered from the university's undergraduate journal. The data do not capture whether research activity outside of the discipline of African American students ultimately helps them complete their STEM degrees. This study simply captures a snapshot of the research interests and activities of STEM students as they matriculate through a STEM-focused HBCU. Further studies of how interdisciplinary research activity informs the career paths of graduates is needed to determine the short- and long-term impacts of interdisciplinary and non-STEM research activity by STEM students.

The data also do not reflect how the research project affected the student's future course of study - for example, if the student changed majors or added a minor as a result of the research project. Only the major indicated by the student at the time he or she submitted research to the undergraduate journal was included in this study. 
FIGURE 1. Student Submissions in Primary Disciplines, Based on Submission Topic

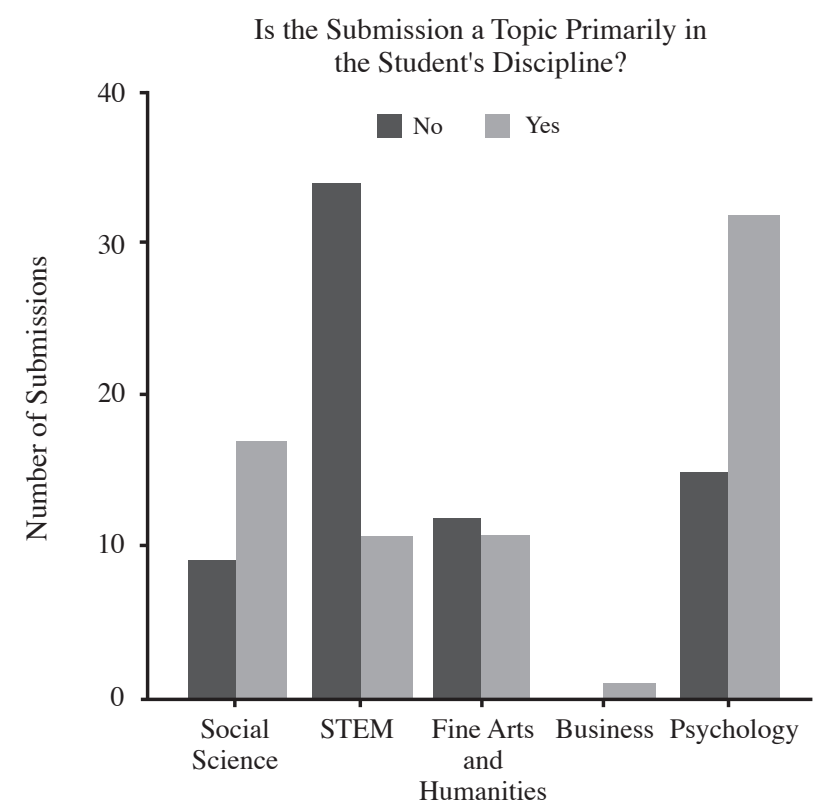

Discipline (Psychology Isolated)

FIGURE 2. Ratio of Student Contributors to the Journal by Discipline, with Psychology Students Isolated

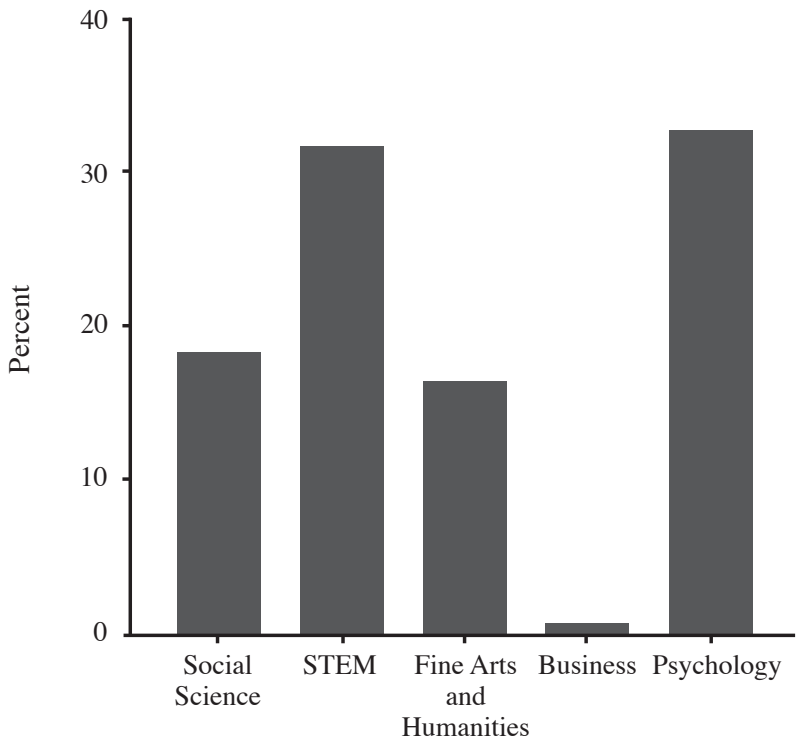

Student Discipline (Psychology Isolated)

These questions underscore the role of a liberal arts curriculum in shaping the educational experience of STEM students, particularly for African American STEM majors. Further research may reveal whether interdisciplinary research shapes the future medical careers and research engagement of these graduates.
FIGURE 3. Ratio of Faculty Mentors by Discipline, with Psychology Faculty Isolated

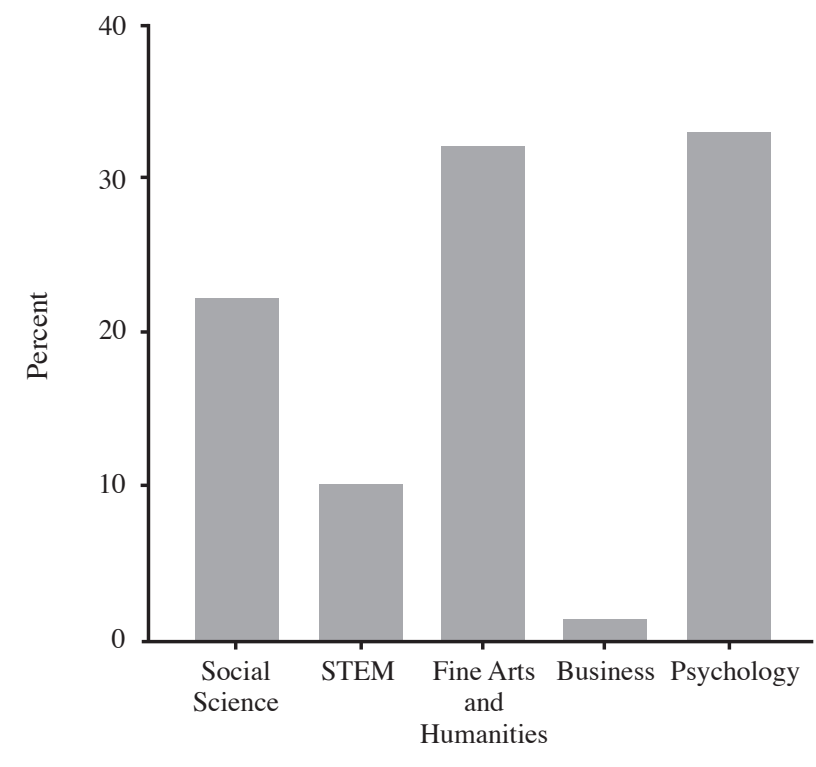

Mentor Discipline (Psychology Isolated)

FIGURE 4. Is the Submission Theme Directly Related to the Mentor's Discipline?

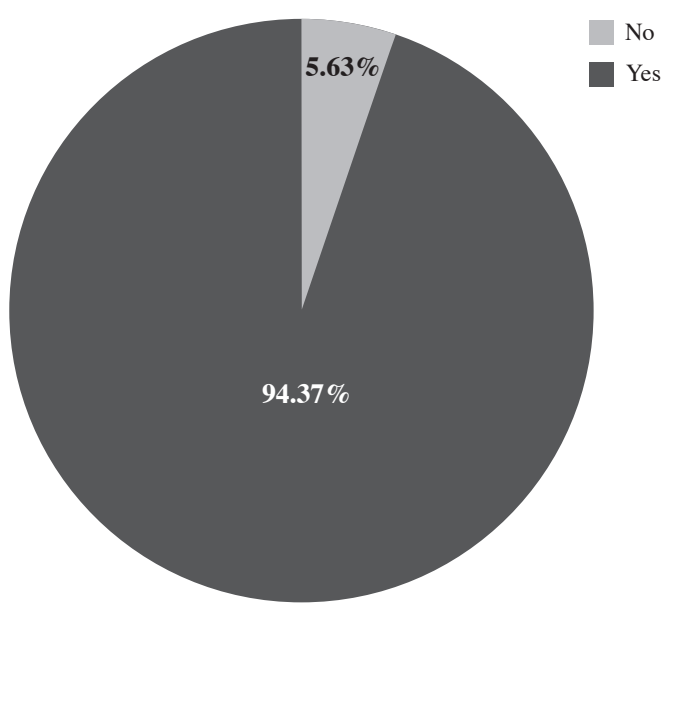

This study underscores the value of the liberal arts education model for African American STEM students. Their agency in pursuing research unrelated or indirectly related to their STEM programs demonstrates their desire to engage in non-STEM research with faculty mentors outside of STEM fields. 
FIGURE 5. Is the Submission Indirectly Connected to the Student's Discipline?

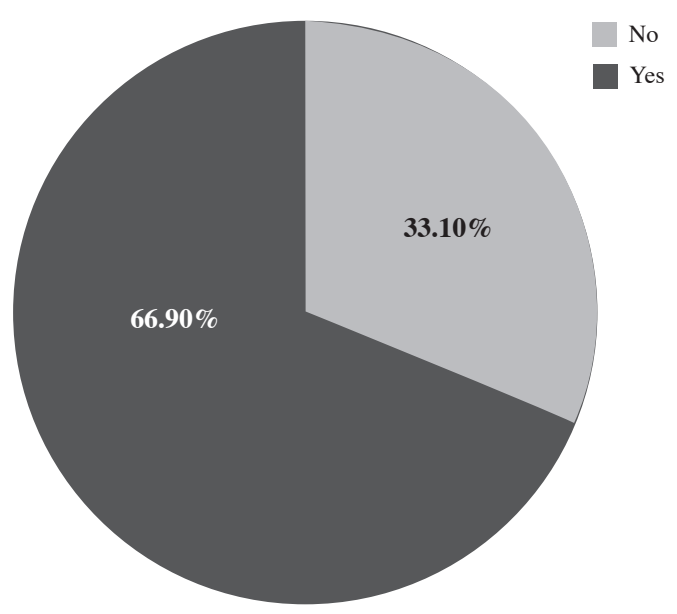

\section{References}

Fakayode, Sayo, Mamudu Yakubu, Olasumbo Adeyeye, David Pollard, and Abdul Mohammed. 2014. "Promoting Undergraduate STEM Education at a Historically Black College and University through Research Experience." Journal of Chemical Education 91: 662-665. doi: 10.1021/ed400482b

Farinde, Abiola, Brett Tempest, and Lisa Merriweather. 2015. "Service Learning: A Bridge to Engineering for Underrepresented Minorities." International Journal for Service Learning in Engineering. Special issue: University Engineering Programs That Impact Communities: Critical Analyses and Reflection, 475-491. doi: 10.24908/ijsle.v0i0.5579

Fife, John, Sherrod Bond, and Angela Byars-Winston. 2011. "Correlates and Predictors of Academic Self Efficacy among African American Students.” Education 132: 141-148.

Fitzsimmons, Lorna. 2016. "Liberal Arts in the Modern University." Academe 102(1): 31-33.

Fries-Britt, Sharon, Toyia Younger, and Wendell Hall. 2010. "Lessons from High-Achieving Students of Color in Physics." In Students of Color in STEM: New Directions for Institutional Research, ed. Shaun Harper, 75-83. San Francisco: Jossey-Bass. doi: 10.1002/ir.363

Hannah-Jones, Nikole. 2015. "A Prescription for More Black Doctors: How Does Tiny Xavier University in New Orleans Manage to Send More African American Students to Medical School Than Any Other College in the Country?" New York Times Magazine, September 12, 2015. https://www.nytimes.com/2015/09/13/ magazine/a-prescription-for-more-black-doctors.html

Haynes, Mariana. 2015. "Building a STEM Pathway: Xavier University of Louisiana's Summer Science Academy." Alliance for Excellent Education. Accessed October 29, 2016. all4ed.org/ reports-factsheets/xavierstem

McClain, Oren. 2014. "Negotiating Identity: A Look at the Educational Experiences of Black Undergraduates in STEM Disciplines." Peabody Journal of Education 89: 380-392. doi: 10.1080/0161956x.2014.913451

30 Scholarship and Practice of Undergraduate Research
Moakler, Martin, and Mikyong Minsun Kim. 2014. "College Major Choice in STEM: Revisiting Confidence and Demographic Factors." Career Development Quarterly 62: 128-142. doi: 10.1002/j.2161-0045.2014.00075.x

Museus, Samuel, Robert Palmer, Ryan Davis, and Dina Maramba. 2011. "Factors That Influence Success among Racial and Ethnic Minority College Students in the STEM Circuit." ASHE Higher Education Report 36(6): 53-85. doi: 10.1002/aehe.v36.6

Owens, Emiel, Andrea Shelton, Collette Bloom, and Kenyatta Cavil. 2012. "The Significance of HBCUs to the Production of STEM Graduates: Answering the Call." Educational Foundations 26(3-4): 33-47.

Palmer, Robert, Dina Maramba, and Elon Dancy. 2011. “A Qualitative Investigation of Factors Promoting the Retention and Persistence of Students of Color in STEM." Journal of Negro Education 80: 491-504.

Pangle, Lorraine Smith. 2013. "Reclaiming the Core: Liberal Education in the Twenty-First Century." Perspectives on Political Science 42: 207-211. doi: 10.1080/10457097.2013.829341

Perna, Laura, Valerie Lundy-Wagner, Noah D. Drezner, Marybeth Gasman, Susan Yoon, Enakshi Bose, and Shannon Gary. 2009. "The Contribution of HBCUs to the Preparation of African American Women for STEM Careers: A Case Study." Research in Higher Education 50: 1-23. doi: 10.1007/s11162-008-9110-y

Smith, Kalynda, Lorraine Fleming, Silas Burris, and Fabiana Bornnman. 2014. "African American Undergraduate Success in Engineering: Proving Them." Presentation at the 121st American Society for Engineering Education Annual Conference and Exposition, Indianapolis.

Strayhorn, Terrell, Bie Fei, Leroy Long, and Blossom Barrett. 2014. "African American and Hispanic STEM Students' Engagement at Predominantly White Institutions." Presentation at the 121st American Society for Engineering Education Annual Conference and Exposition, Indianapolis.

US Department of Education. 2016. "Fact Sheet: Spurring African American STEM Degree Completion." White House Initiative on Educational Excellence for African Americans. Accessed October 29, 2016. https://www.ed.gov/news/press-releases/factsheet-spurring-african-american-stem-degree-completion

Xavier University of Louisiana. 2016. "University Mission Statement." Accessed October 29, 2016. http://www2.xula.edu/ mission

Xavier University of Louisiana College of Arts and Sciences. 2016. "Affordable, Quality Education with Proven Results!" Accessed October 29, 2016. http://www2.xula.edu/cas/index.html

\section{Shearon Roberts}

Xavier University of Louisiana, srobert7@xula.edu

Shearon Roberts is an assistant professor of mass communication and affiliate faculty for the African American and Diaspora Studies program at Xavier University of Louisiana. She served as an associate director of Xavier's Center for Undergraduate Research and as interim editor for Xavier's undergraduate research journal, XULAneXUS. 
She earned a PhD in Latin American and Caribbean studies from Tulane University and has coauthored and coedited books and peer-reviewed journal articles.

Ross Louis is a professor of communication studies and teaches honors courses in public speaking at Xavier University of Louisiana. He has been an associate director of Xavier University's Center for Undergraduate Research for nine years. He is also the editor for XULAneXUS. He is one of the founding faculty members of Xavier University's performance studies lab and Performance Studies program and previously served as faculty-inresidence for service learning at Xavier's Center for the Advancement of Teaching and Faculty Development. He earned a PhD in communication studies with an emphasis in performance studies at Louisiana State University.

\title{
Interested in reviewing books for SPUR?
}

\section{Have a title to suggest for review?}

\section{Contact SPUR's book review editor:}

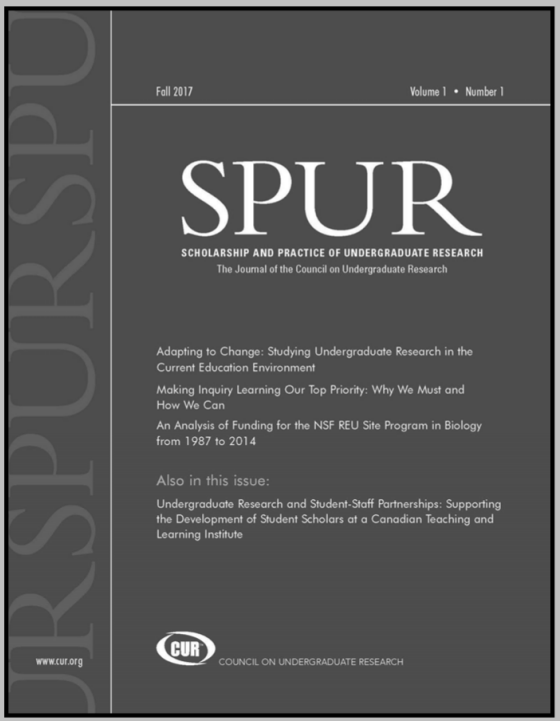

\author{
Nicholas J. Rowland, Penn State Altoona \\ njr12@psu.edu
}

